\title{
THE ROLE OF TRANSPARENCY ON THE INTENTION TO DONATE MONEY TO CHARITABLE ORGANIZATIONS: A COMBINATION OF MULTIPLE CORRESPONDENCE ANALYSIS AND CONJOINT ANALYSIS
}

\author{
Nguyen Van Anha, ${ }^{a,}$, Nguyen Thi Phuong Thao ${ }^{a, b}$, Kim Sung Ho ${ }^{b}$ \\ ${ }^{a}$ The Faculty of Economics \& Business Administration, Dalat University, Lamdong, Vietnam \\ ${ }^{b}$ Marketing Department, Hanyang Business School, Hanyang University, South Korea
}

\author{
Article history \\ Received: June $17^{\text {th }}, 2016 \mid$ Received in revised form: September $30^{\text {th }}, 2016$ \\ Accepted: November 02 ${ }^{\text {nd }}, 2016$
}

\begin{abstract}
This study empirically investigated the effects of levels of attributes of charitable organizations (COs) on potential donor's intention to donate to COs by using conjoint analysis combine with multi correspondence analysis (MCA). The current study was carried out by employing questionnaire survey method. A sample of 181 respondents participated in the study. Based on previous studies, we selected four attributes which compose COs. These are: (1) Reputation (well-known/not well-known); (2) Types of activities (wildlife charity/environmental charity/humanitarian charity); (3) Benefits offered to donors (invitations to special charity gala and events/fiscal incentives/high personal recognition), and transparency (high/low). The findings of the study are as follows: (1) The most important attribute is transparency, followed by the types of activities, and benefits offered to donors. The reputation of COs turns out to be least important; (2) High transparency and COs activities of humanitarian charity have the biggest impact on the intention of donating. Managerial implications, limitations and direction for future research are discussed.
\end{abstract}

Keywords: Charitable organization; Conjoint analysis; Multi correspondence analysis; Reputation; Rewards and benefits offered; Transparency; Types of activities.

\section{INTRODUCTION}

Korean people donate significantly to charitable organizations; However, the levels of charitable giving in Korea are much lower than in many other developed countries, such as the US, the UK, Hong Kong, and Singapore (Charities Aid Foundation, 2014). In 2014, Korea ranked 40th of 153 countries in relative to donate money to charitable organizations (Charities Aid Foundation, 2014). This ranking is not really high in comparison with others having lower economic development than Korean economics. 
Therefore, it really needs to understand Korean donors' attitude in order to improve their donative behaviors and what really motivates an individual to make a monetary donation.

In today's era of evaporating operating profits, numerous organizations, including hospitals, universities and not-for-profit entities are increasingly focusing on charitable giving as a funding source. The reason here is that because of dropping government support for charity organizations, charity organizations are much more dependent on the support of the general population (Smith \& McSweeney, 2007). Moreover, charitable organizations are under increasing financial pressure to attract and retain private donors but researches examining consumer attitudes toward and motivations for giving to charity have yielded ambiguous results (Webb, Green, \& Brashear, 2000). Therefore, it seems very critical for charitable organizations to know what factors they can focus on to motivate the people to donate money.

Actually, there are several researches about intention to donate for charitable organizations. However, some of those focused only on demographic characteristics to predict for donate intention without caring about factor related to characteristics of charitable organizations (Bennett, 2003; Brunel \& Nelson, 2000), while others of those added other factors such as reputation of charity, type of cause, ...but almost these researches used ANOVA or MACOVA method and different regression methods to examine research model and predict the effects of the factors on intention to donate (Bennett, 2003; Buchheit \& Parsons, 2006; Cheung \& Chan, 2000; Michel \& Rieunier, 2012; Paço et al., 2014; Snipes \& Oswald, 2010). However, in real world sometimes donors have to make trade off based on several key factors to donate money for a charitable organization. To deal with this conjoint analysis method takes advantage rather than other methods. The goal of the conjoint survey is to assign specific values to the range of options potential donors considered when making a decision on whether to donate. Conjoint analysis implies that decisions are made on the basis of trade-offs among the different product characteristics. The individual determines which combinations of product attributes are the most and least important and ranks them accordingly (Kottasz, 2004). 
Besides, in recent years, there has been a growth of the number of non-profit organizations that increase competitive levels inside the sector for both public and private funding (Bendapudi et al., 1996; Frumkin \& Kim, 2001). Given this, it is no doubt that the knowledge of which attribute is the most important one influence donor giving would be of great benefit to fund-raisers and development officers alike to formulate the effective donation strategy. However, Peltier et al. (2002) denotes that most organizations have not gained full knowledge of why their donors perform as they do and what can be done to influence those behaviors. Hence, in this paper we review some factors that affect donate intention. Specifically, we employ conjoint analysis to determine which attribute has the largest impact on donate intention. We also examine to what extent the influences of these attributes are related to donor demographics and give some marketing strategies based on segmentation.

\section{LITERATURE REVIEW}

This study used conjoint analysis to examine the relative importance weights for characteristics of charitable organizations that influence people's intention to donate money. Conjoint analysis has been widely used in marketing to evaluate consumer preferences for products and services (Hair et al., 1998). The necessary data to carry out conjoint analysis consisted of people evaluations of alternative charitable organizations described as sets of attributes levels of the charitable organization's characteristics.

Table 1. Selected attributes

\begin{tabular}{ll}
\hline Attributes & Literature review \\
\hline Reputation & $\begin{array}{l}\text { Bennett and Gabriel (2003); Fombrun and Shanley (1990); Kottasz (2004); } \\
\text { Saxton (1998); Snipes and Oswald (2010). }\end{array}$ \\
$\begin{array}{l}\text { Type of cause } \\
\text { Rewards and benefits } \\
\text { offered }\end{array}$ & Kottasz (2004); Sargeant et al. (2001); Sargeant et al. (2006). \\
$\begin{array}{l}\text { Transparency } \\
\text { Ayan et al. (2012); Bothwell (2004); Buchheit and Parsons (2006); Burger }\end{array}$ \\
\hline
\end{tabular}

Attribute levels of charitable organizations must be chosen carefully to represent what would be realistic in our society, and should cover the entire range of representative 
levels. Based on literature review, we then used depth interview method to discuss about which attributes would be chosen as shown in Table 1.

\subsection{Reputation}

Some previous studies have indicated that donors are motivated in part by the reputation of organizations (Andreoni \& Scholz, 1998; Peltier et al., 2002). Reputation refers to a value judgment about an organization's qualities that built up over a period and focusing on what it does and how it behaves (Balmer, 1998). Thus, reputation has a historical dimension since it represents 'the estimation of the consistency over time of an attribute of an entity, based on its willingness and ability to perform an activity repeatedly in a similar fashion' (Herbig \& Milewicz, 1995). Similarly, Fombrun and van Riel (1997) emphasize the historical nature of reputation which, they suggest, is a 'subjective, collective assessment of an organization's trustworthiness and reliability' based on past performance. Moreover, if a charity has a good reputation, it would enable that charity to stimulate trust, encourages donor loyalty, and enhances the organization's competitive (fund-raising) position (Fombrun \& Shanley, 1990). Reputation, moreover, could be crucial to a charity's ability to reach beneficiaries. Fombrun and Shanley (1990) note how a good reputation can serve as a value signal in situations of information overload, complexity or inadequacy. People frequently employ their perceptions of an organization's reputation to interpret 'ambiguous information signals' about it and hence to 'gauge its relative merits' (Fombrun \& Shanley, 1990). Arguably, reputational judgments create expectations in the public mind about how a charity will behave in the future (Saxton, 1998) and thus may affect long-term willingness to donate to the charity (Sargeant, West, \& Ford, 1999) and the latter's ability to attract volunteers and highquality staff (Paton, 2002). In addition, Snipes and Oswald (2010) show that reputation of a charity has the largest influence on consumers' charitable giving decisions.

\subsection{Transparency}

Transparency of charitable organizations plays a vital role in decision making process to donate. There are a number of studies have found positive relationship between the extent of disclosure levels and the amount of future donations received (Behn et al., 
2007; Christensen \& Mohr, 2003; Parsons, 2003; Trussel \& Parsons, 2007). These studies use the extent of voluntary disclosures based on annual reports that are hypothesized to impact the charity donation decisions. In other studies, NPOs websites have been found to be more effective tool in providing financial and performance disclosure for the stakeholders' in making decision (Gandia, 2011; Saxton \& Guo, 2011).

Transparency is the deliberate attempt to make available all legally releasable information - whether positive or negative in nature - in a manner that is accurate, timely, balanced, and unequivocal, for the purpose of enhancing the reasoning ability of publics and holding organizations accountable for their actions, policies, and practices (Rawlins, 2009).

Transparency of charitable organizations refers to level of voluntary disclosed of financial and non-financial information. The financial information provided by charity can be one of the factors affecting the extent of disclosure and consequently influences a potential donor's decision to donate. Previous studies provide evidence that financial reports play a role in donation decision (Hyndman, 1990; Hyndman, 1991; Khumawala \& Gordon, 1997; Parsons, 2007; Weisbrod \& Dominguez, 1986). Through financial reports issued by the charity organizations, donors can obtain necessary information for them to assess and evaluate the performance efficiency of the organization. Performance efficiency is often used in disclosure studies and is also found to positively affect the charity donations (Callen, 1994; Tinkelman, 1998).

The disclosures beyond financial information are considered as supplemental disclosures of non-financial information. Non-financial information presented through Service Efforts and Accomplishments (SEA) disclosures are to complement and supplement the financial information. According to Buchheit and Parsons (2006), supplementing information with SEA information was significantly found to have increased the donors' perception towards the charity organizations and increase the percentage of potential donors to donate to the charity organization in the future (Buchheit \& Parsons, 2006). 
In summary, it argues that transparency of information voluntary reported is very important for donors' decision making process.

\subsection{Rewards and benefits offered}

The determinants of charitable giving refer to the underlying individual motives for electing to support a charity. It has been argued that individuals may choose to help others because they expect some economic or social reward for doing so (Collard, 1978). The motivation for helping may be egoistic, altruistic or both. Egoistic motivation has the ultimate goal of increasing a person's own welfare by gaining rewards for helping, or avoiding punishment for not helping (Cialdini et al., 1990). These rewards and punishments include intangible cognitive and psychological outcomes, as well as tangible benefits and penalties; They also may be donated by the person (e.g., pride versus guilt) or by society (e.g., praise versus condemnation). Egoistic motivations extend to such issues as securing recognition, a sense of belonging, career advancement, tax advantages, peer pressure and political gains.

Furthermore, literature has alleged that today's donors are increasingly interested in getting benefits and rewards from the charities they support. According to a survey of UK fundraisers revealed that many believed that, in return for their investment, rich donors prefer to receive tangible (or service) benefits such as, for example, invitations to special events and membership schemes (Kottasz, 2004). It suggests that the most direct way to add donor value was to offer more fiscal incentives to individuals and increase the value of the gift itself by matched giving via tax breaks (Kottasz, 2004).

\subsection{Type of activities}

The characteristics of a charity organization as well as area that the charity organization chooses could be a factor considered when people are opting to donate money to that organization. For instance, it seems logical that there is a higher intention to donate to a charity organization when the donor has affinity with the cause or mission of the organization and supports the goals of the organization (Sargeant \& Woodliffe, 2007). It is also possible that the objective of the charity organization has an influence on people's intention to donate to the organization. Some people may be more willing to 
donate money to support medical research, while others would support an organization that takes care of orphans. Bennett (2003) shows with his research that personal values could have an influence on the type of charity organization a person chooses to donate to. Hibbert and Home (1997) also acknowledged the importance of a cause that is dear to the heart of the donors.

Since charity organizations are value-expressive products and offer intangible efforts, most people donate to a charity organization that shares their values (Brunel $\&$ Nelson, 2000). Sargeant and Woodliffe (2007) investigate the antecedents of donor commitment and loyalty to a charity organization. They found out that the extent to which a person shares the beliefs of the charity organization is a main determinant of active commitment to the organization. Therefore, affinity with the cause of a charity organization could have a positive effect on a person's intention to continue donating to that charity organization. In accordance with the findings of the authors mentioned before we can infer that when people have affinity with the cause or mission of the charity organization this will lead to a higher intention to continue donating to that charity organization. Based on discussion above, we summarize attributes and their levels to use for individual's evaluating (Table 2).

Table 2. Attributes and their levels

\begin{tabular}{ll}
\hline Attributes & Levels \\
\hline \multirow{3}{*}{ Rewards and benefits offered } & (1) Invitations to special charity galas and events \\
& (2) Fiscal incentives \\
& (3) High personal recognition \\
& (1) Well-Known \\
Reputation & (2) Not Well-Known \\
& (1) Environmental charity \\
Type of activities & (2) Humanitarian charity \\
& (3) Wildlife charity \\
Transparency & (1) High \\
& (2) Low \\
\hline
\end{tabular}




\section{METHODOLOGY}

The goal of the conjoint survey is to assign specific values to the range of options potential donors considered when making a decision on whether to donate. Conjoint analysis implies that decisions are made on the basis of trade-offs among the different product characteristics. The individual determines which combinations of product attributes are the most and least important and rate them accordingly. Each characteristic has a 'part-worth' reflecting its perceived relative importance.

This research attempts to overcome some of the flaws of previous studies. In particularly, it will include more variables, in order to create a more realistic scenario. This will improve the validity of the findings. Besides, it will include variables which were not tested in previous studies. Therefore, this study will explain the joint influence of several variables, as explained below. It will also include certain demographics in order to provide a classification of individuals according to the utility and importance attached to the variables measured in this study.

As mentioned above, most of the experiments followed an experimental design $2 \times 2$ or $2 \times 3$. In this study, the methodology used is known as conjoint analysis. There are four advantages of conjoint analysis over other experimental designs (Green et al., 2001; Hair et al., 1998). Firstly, it allows users to test a wide range of independent variables at the same time. Therefore, it allows users to build more realistic scenarios, as more variables are used to define them. Secondly, the previous requirements of normality or co linearity are less rigid than in traditional experimental designs (ANOVA or MANOVA). Finally, it is a decomposition model (as opposed to discriminant analysis or regression analysis): Interviewees give a global rating and, from these data, researchers infer the importance and utility obtained with each factor/level. This last feature of conjoint analysis helps to prevent the desirability bias. Because interviewees choose a particular product or "bundle of attributes", it is more difficult to overstate a preference for a particular factor to "please" the researcher.

The underlying assumption is that any set of stimuli is evaluated as a bundle of attributes. For the interviewee, the task is relatively easy, as he/she only has to rank or 
rate every card presented (a combination of attributes and levels). In this study, we find out the right combination of attributes that incorporate in the value proposition of features' charitable organizations. These attributes could be considered the key success factors of attract potential donor.

According to Hair et al. (1998), the first step in this methodology is to identify the most relevant set of attributes used by potential donor when choosing a charitable organization. As we mentioned above, we used different sources to determine the most relevant attributes and their levels such as literature review and in-depth interviews. The attributes and levels which potential donors consider included in the conjoint analysis study, are summarized in Table 2.

The next step is to create cards based on selected attributes. With four attributes and levels gives rise to 36 possible scenarios $(2 \times 3 \times 3 \times 2)$. It would definitely be difficult for respondents to rate or rank their preferences for so many scenarios. Therefore, we used SPSS software with orthogonal design methods which applies fractional factorial designs to produce an orthogonal main-effects design, which ensure not only the absence of multi-collinearity between attributes (Silayoi \& Speece, 2007) but also reduce the number of scenarios which helps respondent rank or score easily. With that method, we create nine cards; it is the combinations of attribute level which resulted and were used in the study are shown in Table 3.

Table 3. Card descriptions

\begin{tabular}{lllll}
\hline Card & Reputation & Type of activities & Rewards and benefits offered & Transparency \\
\hline 1 & Well-Known & Humanitarian Charity & High personal recognition & High \\
2 & Well-Known & Wildlife Charity & Invitations to special charity galas & Low \\
3 & Not Well-Known & Environmental Charity & High personal recognition & Low \\
4 & Not Well-Known & Wildlife Charity & Fiscal incentives (tax break) & High \\
5 & Not Well-Known & Humanitarian Charity & Invitations to special charity galas & High \\
6 & Well-Known & Wildlife Charity & High personal recognition & High \\
7 & Well-Known & Environmental Charity & Invitations to special charity galas & High \\
8 & Well-Known & Environmental Charity & Fiscal incentives (tax break) & High \\
9 & Well-Known & Humanitarian Charity & Fiscal incentives (tax break) & Low \\
\hline
\end{tabular}


The third step in conjoint analysis is to develop the questionnaire. There are three sections in our questionnaire: 1) A set of definitions and examples of each term used, and the instructions on how to fill in the questionnaire; 2) Cards to be rated; 3) Demographic details and questions about whether respondents have ever donated or not.

After analyzing data with conjoint method, we continued to use those results to apply for Multiple Correspondence Analysis to discover structure of sample which could help charitable organization managers give suitable strategies for each group. MCA analysis quantifies nominal (categorical) data by assigning numerical values to the cases (objects) and categories so that objects within the same category are close together and objects in different categories are far apart. Each object is as close as possible to the category points of categories that apply to the object. In this way, the categories divide the objects into homogeneous subgroups. Variables are considered homogeneous when they classify objects in the same categories into the same subgroups.

\section{RESULTS}

\subsection{Sample descriptions}

This study used convenience sampling at School of Business in Hanyang University, South Korea. A sample of 260 undergraduate and graduate students recruited in December 2015 through business classes with supporting of professors. Respondents were briefly explained about the purpose of the study before the questionnaire was administered. There are 211 collected questionnaires but after scanning data, 30 respondents did not qualify for analysis due to lack of important information, answering inaccurately. Finally, 181 respondents were used to analyze, descriptive sample is showed in Table 4.

Sample descriptions showed that the percentage of males and females who participated in this study was quite the same. However, slightly over two-thirds of respondents were young people $(71.3 \%)$ and had ever donated their money for charitable organizations $(70.2 \%)$. 
Table 4. Sample descriptions

\begin{tabular}{llcc}
\hline \multirow{3}{*}{ Gender } & & Frequency & Percent \\
\cline { 3 - 4 } Age & Fale & 94 & 51.9 \\
& $20-29$ & 87 & 48.1 \\
& $30-39$ & 129 & 71.3 \\
& $40-49$ & 29 & 16.0 \\
Donation & Equal or Above 50 & 18 & 9.9 \\
& Yes & 5 & 2.8 \\
Education & No & 127 & 70.2 \\
& University Student & 54 & 29.8 \\
Total & Graduate student & 109 & 60.2 \\
\hline
\end{tabular}

\subsection{Results and analysis}

\subsubsection{Conjoint analysis}

The conjoint results in Table 5 show that the validity of the model for the whole sample ( $\mathrm{n}=181)$ through the Pearson's R and the Kendall's Tau are high (0.994 and 0.944, respectively), which indicates that the model fits the data well.

Table 5. Results of conjoint analysis $(n=181)$

\begin{tabular}{llcc}
\hline Attribute & Level & Utility & $\begin{array}{c}\text { Relative } \\
\text { importance (\%) }\end{array}$ \\
\hline Reputation & Well-Known & 5.005 & 16.59 \\
& Not Well-Known & -5.005 & \\
Type of activities & Environmental Charity & -2.049 & \\
& Humanitarian Charity & 6.417 & 24.63 \\
& Wildlife Charity & -4.368 & \\
Rewards and benefits & Invitations to special charity galas & -2.312 & \\
offered & and events & & \\
& Fiscal incentives (e.g., tax break) & 1.886 & \\
Transparency & High personal recognition & 0.426 & \\
& High & 14.272 & 38.36 \\
\hline
\end{tabular}

Note: Pearson's R = 0.994; Kendall's tau $=0.944$, with both significant at 0.000 
The conjoint analysis results also indicate that transparency of charitable organizations with the relative importance is about 38\%, which plays the most important role in potential donor likelihood to donate. The relative importance of next attributes is type of cases, reward and benefits offered and reputation of charity with around $24.6 \%$, $20.4 \%$ and $16.6 \%$, respectively (Table 5).

Table 5 also shows the average utilities of each attribute levels which describe the desirability of the range of an attribute, with higher scores suggesting that respondents had a larger preference for that aspect. In particularly, the positive utility of 14.272 for high transparency while negative utility of -14.272 for low transparency indicates that people intend to donate for charitable organizations which have high transparency. The result consists of previous studies about transparency in nonprofit organizations (Buchheit \& Parsons, 2006; Khumawala \& Gordon, 1997; Parsons, 2007; Weisbrod \& Dominguez, 1986).

For type of causes, humanitarian charity has a positive utility score of 6.417 in comparison with the rest of levels have negative utility score. It means that respondent in this research like to donate for charitable organizations service for human than others (wildlife or environment).

For rewards and benefits offered attribute, fiscal incentives have highest positive utility (1.886) which shows that people also like to receive back some tangible benefits when they donate for charity. Therefore, manager and policy maker should care about it when making strategies to improve donative behavior in Korea.

For reputation attribute respondents prefer well-known charity to not well-known ones. It is represented at two utilities scores 5.005 and - 5.005, respectively. The results confirm previous researches' results about reputation role in organization when people decide whether to donate (Kottasz, 2004; Snipes \& Oswald, 2010).

\subsubsection{Multiple correspondence analysis}

Based on the part-worth of attribute levels from conjoint analysis, we transferred metric data into non-metric data, then using MCA to discover structure of the data. First, 
we have data structure from conjoint analysis presented in Table 6.

Table 6. Path-worth of attribute levels

\begin{tabular}{ccccccccccc}
\hline & \multicolumn{3}{c}{ Reputation } & \multicolumn{3}{c}{ Type of cause } & \multicolumn{3}{c}{ Rewards and benefits } & \multicolumn{2}{c}{ Transparency } \\
\cline { 2 - 11 } $\mathrm{n}$ & $\begin{array}{c}\text { Well- } \\
\text { known }\end{array}$ & $\begin{array}{c}\text { Not } \\
\text { well- } \\
\text { known }\end{array}$ & Environment & Human & Wildlife & Invitations & $\begin{array}{c}\text { Fiscal } \\
\text { incentives }\end{array}$ & Recognition & High & Low \\
\hline 1 & -8.33 & 8.33 & -8.89 & -2.22 & 11.11 & 7.78 & -5.56 & -2.22 & 1.67 & -1.67 \\
2 & 10.00 & -10.00 & -3.33 & 36.67 & -33.33 & -3.33 & 10.00 & -6.67 & 7.50 & -7.50 \\
3 & 10.00 & -10.00 & -3.33 & 6.67 & -3.33 & 0.00 & 0.00 & 0.00 & 15.00 & -15.00 \\
4 & 2.50 & -2.50 & 3.33 & 10.00 & -13.33 & -3.33 & 0.00 & 3.33 & 5.00 & -5.00 \\
5 & 23.33 & -23.33 & -14.44 & 2.22 & 12.22 & 2.22 & -4.44 & 2.22 & 15.83 & -15.83 \\
6 & 10.83 & -10.83 & -7.78 & 8.89 & -1.11 & -1.11 & -4.44 & 5.56 & 23.33 & -23.33 \\
7 & 10.00 & -10.00 & 6.67 & -3.33 & -3.33 & 0.00 & 3.33 & -3.33 & 7.50 & -7.50 \\
8 & -9.17 & 9.17 & -24.44 & -4.44 & 28.89 & -14.44 & 2.22 & 12.22 & 28.33 & -28.33 \\
$\ldots$ & $\ldots$ & $\ldots$ & $\ldots$ & $\ldots$ & $\ldots$ & $\ldots$ & $\ldots$ & $\ldots$ & $\ldots$ & $\ldots$ \\
181 & 1.67 & -1.67 & -2.22 & -2.22 & 4.44 & -5.56 & 1.11 & 4.44 & 6.67 & -6.67 \\
\hline
\end{tabular}

We then used the Maximum Utility Rule - the charity profile with the highest attribute utility which is assumed to be the choice to donate of a donor to create nonmetric data presented in Table 7.

Table 7. Non-metric data of attributes

\begin{tabular}{ccccc}
\hline $\mathrm{n}$ & Reputation & Type of cause & Rewards and benefits & Transparency \\
\hline 1 & 2 & 3 & 1 & 2 \\
2 & 1 & 2 & 2 & 2 \\
3 & 1 & 3 & 1 & 1 \\
4 & 2 & 1 & 3 & 2 \\
5 & 1 & 3 & 1 & 1 \\
6 & 1 & 3 & 3 & 1 \\
7 & 1 & 1 & 1 & 2 \\
8 & 2 & 3 & 3 & 1 \\
$\ldots$ & $\ldots$ & $\ldots$ & $\ldots$ & $\ldots$ \\
181 & 2 & 3 & 3 & 2 \\
\hline
\end{tabular}

Note: Reputation: 1-well-known, 2-not well-know; Type of activities: 1-environment, 2-human, 3-wildlife; Rewards and benefits: 1-invitations, 2-fiscial incentives, 3-recognition; 
Finally, we added some demographic variables to apply for MCA (Table 8).

Table 8. Cross-table of non-metric data

\begin{tabular}{cccccccc}
\hline $\mathrm{n}$ & Reputation & Type of activities & Rewards and benefits & Transparency & Donated & Gender & Age \\
\hline 1 & 2 & 3 & 1 & 2 & 2 & 2 & 1 \\
2 & 1 & 2 & 2 & 2 & 1 & 2 & 3 \\
3 & 1 & 3 & 1 & 2 & 2 & 1 & 1 \\
4 & 2 & 1 & 3 & 2 & 2 & 2 & 1 \\
5 & 1 & 3 & 1 & 2 & 1 & 2 & 1 \\
6 & 1 & 3 & 3 & 2 & 2 & 1 & 1 \\
7 & 1 & 1 & 1 & 2 & 1 & 1 & 1 \\
8 & 2 & 3 & 3 & 2 & 1 & 1 & 2 \\
$\ldots$ & $\ldots$ & $\ldots$ & $\ldots$ & $\ldots$ & $\ldots$ & $\ldots$ & $\ldots$ \\
181 & 2 & 3 & 3 & 2 & 2 & 1 & 1 \\
\hline
\end{tabular}

Note: Reputation: 1-well-known, 2-not well-know; Type of activities: 1-environment, 2-human, 3wildlife; Rewards and benefits: 1-invitations, 2-fiscial incentives, 3-recognition; Transparency: 1-low, 2high; Donated: 1-have donated, 2-not yet; Gender: 1-male, 2-female; Age: 1-20s, 2-30s, 3-40s

Using Multiple Correspondence analysis technique (MCA), the results show that there are 3 distinct groups (Figure 1).

- Characteristics of Group 1: Age: 30-39, environment oriented, well known charity organization, male.

- Characteristics of Group 2: Age: 20-29, wild life oriented, unwell- known charity organization, female, invitation and high recognition.

- Characteristics of Group 3: Age: 40-49, human oriented, incentive such as tax break.

Based on the structure of groups, managers can make appreciate strategies to attract more and more potential donors. 


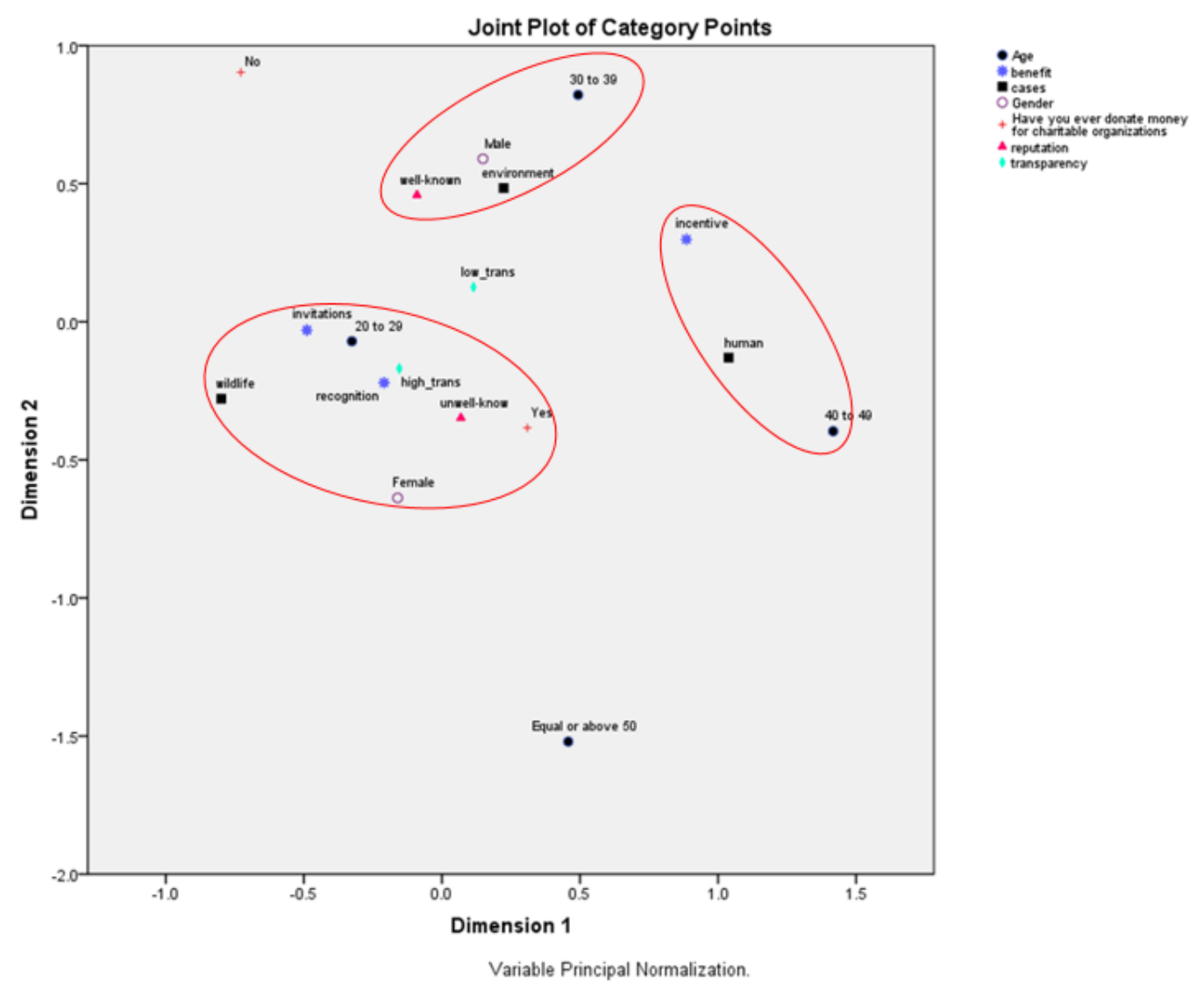

Figure 1. Result of MCA

\section{CONCLUSIONS, LIMITATIONS AND FUTURE RESEARCH}

This research provides some implications for fundraisers as well as managers of charitable organizations whose purpose is promoting donating activities in Korea. First of all, managers should emphasize the transparency of charity activities such as disclosure information related of the way they use the donated money as well as effectiveness of charity activities. Moreover, disclosure charity financial statement also plays a vital role since the donors tend to consider this factor before making their contribution decisions. This study adds to the body of research which has been conducted in the charitable giving area to help us better understand the relationship between transparency and intention to donate simultaneously consider other attributes such as reputation, types of causes as well as rewards and benefit offered.

Interestingly, based on the results of MCA, three groups have distinctive characteristics that can help fundraisers formulate different strategies that can effectively 
attract donors as well as motivate people to donate more and more. For example, it is likely with the human oriented charitable organizations whose potential donors are people from 40 to 49 years old and one way to motivate them is to give them fiscal incentives like tax break. Also, with the charity organizations that focus on the environment matters, their potential donors are 30-39 and they should focus on building their reputation and image. Besides, it seems effective to attract the donors for the wildlife oriented charitable organizations which are creating more and more events as well as inviting donors to the special events or galas, and create opportunities for them to be highly recognized; the young people tend to be inclined to give their money to the organization.

One limitation of this study is the sample. While taken on separate days, the sample was collected at one location in Business School of Hanyang University. For all practical purposes, the sample was a convenient sample. The demographics of this study may not be representative of the entire South Korean population, but the results have provided a starting point for future research. Future research should perhaps look at a more stratified sample design with multiple locations that may yield differing results. That said, a replication of this study in multiple locations is warranted.

\section{REFERENCES}

Andreoni, J., \& Scholz, J. K. (1998). An econometric analysis of charitable giving with interdependent preferences. Economic Inquiry, 36, 410-428.

Balmer, J. M. T. (1998). Corporate identity and the advent of corporate marketing. Journal of Marketing Management, 14(8), 963-996.

Behn, B. K., DeVries, D., \& Lin, J. (2007). Voluntary disclosure in nonprofit organizations: An exploratory study. Working paper. Retrieved from https://ssrn.com/abstract=727363 or http://dx.doi.org/10.2139/ssrn.727363

Bendapudi, N., Singh, S. N., \& Bendapudi, V. (1996). Enhancing helping behavior: An integrative framework for promotion planning. The Journal of Marketing, 60(3), 3349.

Bennett, R. (2003). Factors underlying the inclination to donate to particular types of charity. International Journal of Nonprofit and Voluntary Sector Marketing, 8(1), 12-29.

Bennett, R., \& Gabriel, H. (2003). Image and reputational characteristics of UK charitable organizations: An empirical study. Corporate Reputation Review, 6(3), 276-289. 
Bothwell, R. O. (2004). Trends in self-regulation and transparency of nonprofits in the U.S. The International Journal of Not-for-Profit Law, 2(3), 1-20.

Brunel, F. F., \& Nelson, M. R. (2000). Explaining gendered responses to "help-self" and "help-others" charity ad appeals: The mediating role of world-views. Journal of Advertising, 29(3), 15-28.

Buchheit, S., \& Parsons, L. M. (2006). An experimental investigation of accounting information's influence on the individual giving process. Journal of Accounting and Public Policy, 25(6), 666-686.

Burger, R., \& Owens, T. (2010). Promoting transparency in the NGO sector: Examining the availability and reliability of self-reported data. World Development, 38(9), 1263-1277.

Callen, J. L. (1994). Money donations, volunteering and organizational efficiency. Journal of Productivity Analysis, 5(3), 215-228.

Charities Aid Foundation. (2014). World giving index 2014: A global view of giving trends. Retrieved from https://www.cafonline.org/docs/default-source/about-uspublications/caf_wgi2014_report_1555awebfinal.pdf

Cheung, C. K., \& Chan, C. M. (2000). Social-cognitive factors of donating money to charity, with special attention to an international relief organization. Evaluation and Program Planning, 23, 241-253.

Christensen, A. L., \& Mohr, R. M. (2003). Not-for-profit annual reports: What do museum managers communicate? Financial Accountability \& Management, 19(2), $139-158$.

Cialdini, R. B., Reno, R. R., \& Kallgren, C. A. (1990). A focus theory of normative conduct: Recycling the concept of norms to reduce littering in public places. Journal of Personality and Social Psychology, 58(6), 1015-1026.

Collard, D. A. (1978). Altruism and economy: A study in non-selfish economics. New York, USA: Oxford University Press.

Fombrun, C. J., \& Shanley, M. (1990). What's in a name? Reputation building and corporate strategy. Academy of Management Journal, 33(2), 233-259.

Fombrun, C., \& van Riel, C. (1997). The reputational landscape. Corporate Reputation Review, 1(2), 5-13.

Frumkin, P., \& Kim, M. T. (2001). Strategic positioning and the financing of nonprofit organizations: Is efficiency rewarded in the contributions marketplace? Public Administration Review, 61(3), 266-275.

Gandia, J. L. (2011). Internet disclosure by nonprofit organizations: Empirical evidence of nongovernmental organizations for development in Spain. Nonprofit and Voluntary Sector Quarterly, 40(1), 57-78.

Green, P. E., Krieger, A. M., \& Wind, Y. (2001). Thirty years of conjoint analysis: Reflections and prospects. Interfaces, 31 (3 - Supplement), 56-73. 
Hair, F. J., Anderson, E. R., Tatham, L. R., \& Black, C. W. (1998). Multivariate data analysis $\left(5^{\text {th }}\right.$ ed.). New Jersey, USA: Prentice-Hall, Englewood Cliffs.

Herbig, P., \& Milewicz, J. (1995). To be or not to be... credible that is: A model of reputation and credibility among competing firms. Marketing Intelligence and Planning, 13(6), 24-33.

Hibbert, S. A., \& Home, S. (1997). Donation dilemmas: A consumer behaviour perspective. Journal of Nonprofit and Voluntary Sector Marketing, 2(3), 261-274.

Hyndman, N. (1991). Contributors to charities - A comparison of their information needs and the perceptions of such by the provides of information. Financial Accountability \& Management, 7(2), 69-82.

Khumawala, S. B., \& Gordon, T. P. (1997). Bridging the credibiiity of GAAP: Individual donors and the new accounting standards for nonprofit organizations. Accounting Horizons, 11(3), 45-68.

Kottasz, R. (2004). How should charitable organisations motivate young professionals to give philanthropically? International Journal of Nonprofit \& Voluntary Sector Marketing, 9(1), 9-27.

Michel, G., \& Rieunier, S. (2012). Nonprofit brand image and typicality influences on charitable giving. Journal of Business Research, 65(5), 701-707.

Paço, A., Rodrigues, R. G., \& Rodrigues, L. (2014). Branding in NGOs - Its influence on the intention to donate. Economics \& Sociology, 7(3), 11-21.

Parsons, L. M. (2003). Is accounting information from nonprofit organizations useful to donors? A review of charitable giving and value-relevance. Journal of Accounting Literature, 22, 104-129.

Parsons, L. M. (2007). The impact of financial information and voluntary disclosures on contributions to not-for-profit organizations: A field-based experiment. Working paper. Retrieved from https://ssrn.com/abstract=406760 or http://dx.doi.org/10. 2139/ssrn.406760

Paton, R. (2002). Aces high: Charity administration costs. Financial Management, 19(7), 40-42.

Peltier, J. W., Schibrowsky, J. A., \& Schultz, D. E. (2002). Leveraging customer information to develop sequential communication strategies: A case study of charitabie-giving behavior. Journal of Advertising Research, 42(4), 23-41.

Ayan, R., Zainon, S., \& Wah, Y. B. (2012). Quality information by charity organizations and its relationship with donations. Paper presented at the 6th WSEAS International Conference on Business Administration (ICBA '12), USA.

Rawlins, B. (2009). Give the emperor a mirror: Toward developing a stakeholder measurement of organizational transparency. Journal of Public Relations Research, 21(1), 71-99.

Sargeant, A., West, D., \& Ford, J. (1999). Charitable giving towards a model of donor behaviour. Journal of Marketing Management, 15(4), 37-41. 
Sargeant, A., Ford, J. B., \& West, D. C. (2006). Perceptual determinants of nonprofit giving behavior. Journal of Business Research, 59, 155-165.

Sargeant, A., West, D. C., \& Ford, J. (2001). Predicting donor value: The role of perceptions. Journal of Marketing Management, 3-4, 407-428.

Sargeant, A., \& Woodliffe, L. (2007). Building donor loyalty: The antecedents and role of commitment in the context of charity giving. Journal of Nonprofit \& Public Sector Marketing, 18(2), 47-68.

Saxton, G. D., \& Guo, C. (2011). Accountability online: Understanding the web-based accountability practices of nonprofit organizations. Nonprofit and Voluntary Sector Quarterly, 40(2), 270-295.

Saxton, M. K. (1998). Where do reputations come from? Corporate Reputation Review, 1(4), 393-399.

Silayoi, P., \& Speece, M. (2007). The importance of packaging attributes: A conjoint analysis approach. European Journal of Marketing, 41(11), 1495-1517.

Smith, J. R., \& McSweeney, A. (2007). Charitable giving: The effectiveness of a revised theory of planned behaviour model in predicting donating intentions and behaviour. Journal of Community and Applied Social Psychology, 17(5), 363-386.

Snipes, R. L., \& Oswald, S. L. (2010). Charitable giving to not-for-profit organizations: Factors affecting donations to non-profit organizations. Innovative Marketing, 6(1), 73-80.

Tinkelman, D. (1998). Differences in sensitivity of financial statement users to joint cost allocations: The case of nonprofit organizations. Journal of Accounting, Auditing \& Finance, 13(4), 377-394.

Trussel, J. M., \& Parsons, L. M. (2007). Financial reporting factors affecting donations to charitable organizations. Advances in Accounting, 23, 263-285.

Webb, D. J., Green, C. L., \& Brashear, T. G. (2000). Development and validation of scales to measure attitudes influencing monetary donations to charitable organizations. Journal of the Academy of Marketing Science, 28, 299-309.

Weisbrod, B. A., \& Dominguez, N. D. (1986). Demand for collective goods in private nonprofit markets: Can fundraising expenditures help overcome free-rider behavior? Journal of Public Economics, 30(1), 83-96.

Zainon, S., Atan, R., Ahmad, R. A. R., \& Wah, Y. B. (2012). Associations between organizational specific-attributes and the extent of disclosure in charity annual returns. International Journal of Mathematical Models and Methods in Applied Sciences, 6(3), 482-489. 


\title{
VAI TRÒ CỦA SỰ MINH BẠCH ĐỐI VỚI Ý ĐỊNH QUYÊN GÓP TIỀN CỦA CÁ NHÂN CHO CÁC TỔ CHỨC TỬ THIÊN: SƯ KẾT HợP GIŨ̉A PHÂN TÍCH TƯƠNG HợP VÀ PHÂN TÍCH LIẾN KẾT
}

\author{
Nguyễn Văn Anh ${ }^{\mathrm{a}, \mathrm{b}^{*}}$, Nguyễn Thị Phương Thảo ${ }^{\mathrm{a}, \mathrm{b}}$, Kim Sung Ho $\mathrm{Ho}^{\mathrm{b}}$ \\ ${ }^{a}$ Khoa Kinh tế và Quản trị Kinh doanh, Trường Đại học Đà Lạt, Lâm Đồng, Việt Nam \\ ${ }^{b}$ Khoa Marketing, Truòng Kinh doanh Hanyang, Đại học Hanyang, Hàn Quốc \\ "Tác giả liên hệ: Email: vananhdhdl@gmail.com
}

Lịch sử bài báo

Nhận ngày 17 tháng 06 năm 2016 | Chỉnh sửa ngày 30 tháng 09 năm 2016

Chấp nhận đăng ngày 02 tháng 11 năm 2016

\section{Tóm tắt}

Nghiên cưu này nhằm khám phá sụ ảnh hưởng của các thuộc tính trong các tổ chức tù thiện đến ý định quyên góp của các cá nhân cho các tổ chức này theo phương pháp phân tích liên kết kết hợp với phân tích tuoong hơp đa biến. Theo đó, nghiên cứu này tiến hành khảo sát và thu thập được 181 bảng trả lời để tiến hành phân tích. Có bốn thuộc tính quan trong của các tổ chức tù thiện được lựa chọn trong nghiên cưu này: (1) Danh tiếng; (2) Các loại hình tù thiện; (3) Các lợi ich cho người làm tù̀ thiện; và (4) Sự minh bạch của các tổ chức tù̀ thiện. Kết quả chính của nghiên cưu: Thư nhất, thuộc tính quan trọng nhất ảnh hưởng đến ý định ủng hộ tiền của các cá nhân cho các tổ chức tù̀ thiện là tính minh bạch của các tổ chức đó. Mức độ quan trọng tiếp theo xếp theo thứ tự giảm dần là lĩnh vực hoạt động của các tổ chức tù thiện, lợi ích mà các nhà tài trợ nhận được, danh tiếng của tổ chức tù̀ thiện. Thứ hai, một tổ chức tù̀ thiện có tính minh bạch cao và các hoạt động tù thiện liên quan đến con người có sức hút mạnh mẽ nhất đến ý định quyên góp của các nhà tài trợ cá nhân. Cuối cùng, nghiên cứu cũng đưa ra một số khuyến nghị mang tính chiến luợc cho nhà quản lý, hạn chế của nghiên cứu cũng nhu hướng nghiên cứu trong tuoong lai.

Từ khóa: Danh tiếng; Lĩnh vực hoạt động từ thiện; Lợi ích nhận được; Minh bạch; Phân tích Liên kết; Phân tích tương hợp; Tổ chức từ thiện. 